\title{
SYSTEMATICS OF NEW WORLD TRISSOLCUS (HYMENOPTERA: SCELIONIDAE): SPECIES RELATED TO T. BASALIS
}

\author{
NORMAN F. JOHNSON \\ Department of Entomology, The Ohio State University, Columbus, Ohio 43210
}

\begin{abstract}
Can. Ent. 117: 431-445 (1985)

The New World species of Trissolcus, exclusive of the flavipes and thyantae species groups, are revised. This encompasses seven species: $T$. basalis (Wollaston) recorded in the southeastern USA, West Indies, Venezuela, and southeastern Brazil; $T$. cosmopeplae (Gahan) from the USA and Canada; $T$. erugatus $\mathrm{n}$. sp. from the western USA and Canada; $T$. hullensis (Harrington) widely distributed throughout Canada, USA, Mexico, Dominica, and Venezuela; $T$. radix $\mathrm{n}$. $\mathrm{sp}$. from Guatemala, Costa Rica, Colombia, Venezuela, and the southeastern USA; $T$. solocis $\mathbf{n}$. sp. from Mexico and the southeastern USA; and $T$. utahensis (Ashmead) from the western USA and Canada. Available host information for each species is summarized. These species are described and an identification key is provided.
\end{abstract}

\section{Résumé}

On a révisé les espèces de Trissolcus du Nouveau Monde à l'exclusion des espèces de flavipes et de thyantae. Sept espèces sont donc inclues: $T$. basalis (Wollaston) est mentionnée dans le sud-est des USA, les Antilles, le Vénézuela et le sud-est du Brésil; $T$. cosmopeplae (Gahan) aux USA et au Canada; $T$. erugatus $\mathrm{n}$. sp. dans l'ouest des USA et du Canada; $T$. hullensis (Harrington) est largement distribuée à travers le Canada, les USA, le Mexique, la République Dominicaine et le Vénézuela; $T$. radix n. sp. au Guatemala, au Costa Rica, en Colombie, au Vénézuela et au sud-est des USA; et $T$. utahensis (Ashmead) dans l'ouest des USA et au Canada. On résume l'information disponible sur les hotes de chaque espèce. On décrit ces espèces et une clé d'identification est fournie.

The genus Trissolcus Ashmead (= Asolcus Nakagawa, Microphanurus Kieffer) is one of the two main groups in the subfamily Telenominae (Hymenoptera: Scelionidae). All species are egg parasitoids of bugs of the superfamily Pentatomoidea (Heteroptera). Many of these hosts are economically important pests; there has thus been interest in species of Trissolcus for use as biological control agents.

The difficulties involved in characterizing the genus Trissolcus have been noted by Nixon (1938) and Kozlov and Lê (1977). Many telenomine species from the tropics possess character states usually attributed to Trissolcus, viz. notauli present, frons sculptured, female antennal clava with six closely articulated antennomeres, and bare eyes. However, these species are extremely unusual in other respects, and some may merit recognition as new genera. However, I believe it is best to delay taking that step until the relationships are better understood so as to be able to recognize monophyletic taxa.

The genus Trissolcus sensu stricto in the New World may be recognized using the keys to scelionid genera of the Holarctic in Masner (1980). The only addition needed to account for the Neotropical fauna is Phanuropsis. This genus may be distinguished in both sexes from all other telenomines by the yellow apical segments of the metasoma. Females also have dense, silvery pubescence on the scutellum; males have the apical ventral surface of the scape strongly expanded into a large tooth. The Telenomus longiventris species 'group may also cause problems; however, it consists of large, elongate species with two distinct submedian rows of setae on the frons below the anterior ocellus. Trissolcus species lack these setal lines and, in general, are rather short, stout animals.

Most of the abbreviations and morphological terms used below are defined by Masner (1980). The claval formula (Bin 1981) is a shorthand representation of the distribution of plate sensilla on the female clavomeres: for example, A11-A7/1-2-2-2-2 indicates that there is a single plate sensillum on the apical antennomere (A11), two on A10,2 on A9, 
etc. The hyperoccipilal carina (hc, Fig. 1), a term introduced by Masncr (1979), refers to a carina that runs continuously across the vertex from one eye to the other, behind the lateral ocelli, and merging with the outer orbit of the eye without joining the occipital carina. The inner orbit of some species is bounded by a distinct furrow that expands in width ventrally; this is referred to as the orbital furrow (of, Figs. 1,2). The term sublateral setae (sl, Fig. 13) refers to one or more pairs of posteriorly directed setae near the sides of the first metasomal tergite (Johnson 1984a); these are distinct from the laterally directed setae inserted near the laterotergite line of flexion.

The species descriptions represent summaries of distinguishing character states and refer to both sexes unless otherwise indicated. Host records are cited only from specimens that I have seen. This revision is based on external morphological characters. I expect that studies of the biology of these wasps will result in the discovery of cryptic species within the concepts I discuss here under a single name.

This revision is based on material from the following institutions and individuals: British Museum (Natural History), London (BMNH); California Academy of Sciences, San Francisco, CA (CAS); Califormia State Department of Food and Agriculture, Sacramento, CA (CDFA); Canadian National Collection of Insects, Arachnids and Nematodes, Ottawa, ON (CNC); Florida State Collection of Arthropods, Gainesville, FL (FSCA); W.A. Jones, USDA, Stoneville, MS; Los Angeles County Museum, Los Angeles, CA (LACM); Museum of Comparative Zoology, Harvard University, Cambridge, MA (MCZ); Snow Entomological Museum, Manhattan, KS; United States National Museum of Natural History, Washington, DC (USNM); University of California, Riverside, CA; University of Idaho, Moscow, ID; and the personal collection of the author (NFJ).

In the key presented below I refer to two species groups: the flavipes and thyantae groups. These two clusters of closely related species are treated individually (see Johnson $1984 b$, 1985). The species discussed here form a much more heterogeneous assemblage. I have chosen to discuss the basic taxonomy now and to defer a phylogenetic analysis.

\section{KEY TO NEW WORLD Trissolcus}

1. Notauli present (e.g. Fig. 12); sublateral setae on $\mathrm{T} 1$ absent $\ldots \ldots \ldots \ldots \ldots \ldots \ldots \ldots \ldots 2$

- Notauli usually absent (e.g. Figs. 13, 14); sublateral setae present on T1 (Figs. 17, 18) . . 3

2. Metapleuron setose (Fig. 12); hyperoccipital carina absent; orbital furrow absent ventrally ....

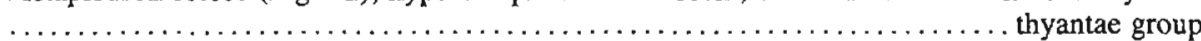

- Metapleuron bare; hyperoccipital carina present (Fig. 1); orbital furrow usually strongly widened

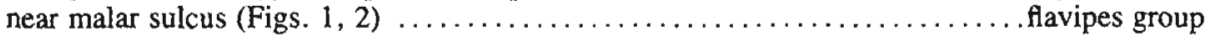

3. Radicle yellow (Guatemala, Costa Rica, Colombia, Venezuela, southeastern United States)

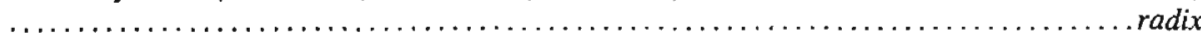

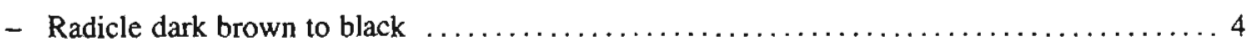

4. T2 with distinct rugulae beyond basal costae (Fig. 18) $\ldots \ldots \ldots \ldots \ldots \ldots \ldots \ldots \ldots$

- T2 smooth beyond basal costae (Fig. 17) ........................... 7

5. Scutellum with distinct coriaceous microsculpture, setal bases usually pustulate (Fig. 14); legs beyond coxae yellow (southeastern United States, West Indies, Venezuela, southeastern Brazil)

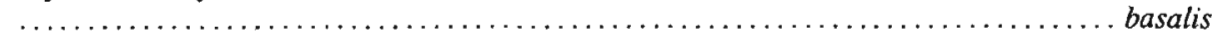

- Scutellum smooth, setal bases not strongly raised (Fig. 16); legs variable in color .......6 6

6. Anterior extension of metapleuron toward mid coxa short (Fig. 6); head, viewed laterally, with malar region distinctly bulging, with no indication of a carina on gena; notauli always absent (western United States and Canada) . utahensis

- Anterior extension of metapleuron toward mid coxa very long (Fig. 3); head, viewed laterally, with malar region narrow, often with a dorsoventral carina on gena; notauli sometimes distinguishable from longitudinal elements of surface sculpture, always very short (United States, Canada) cosmopeplae 

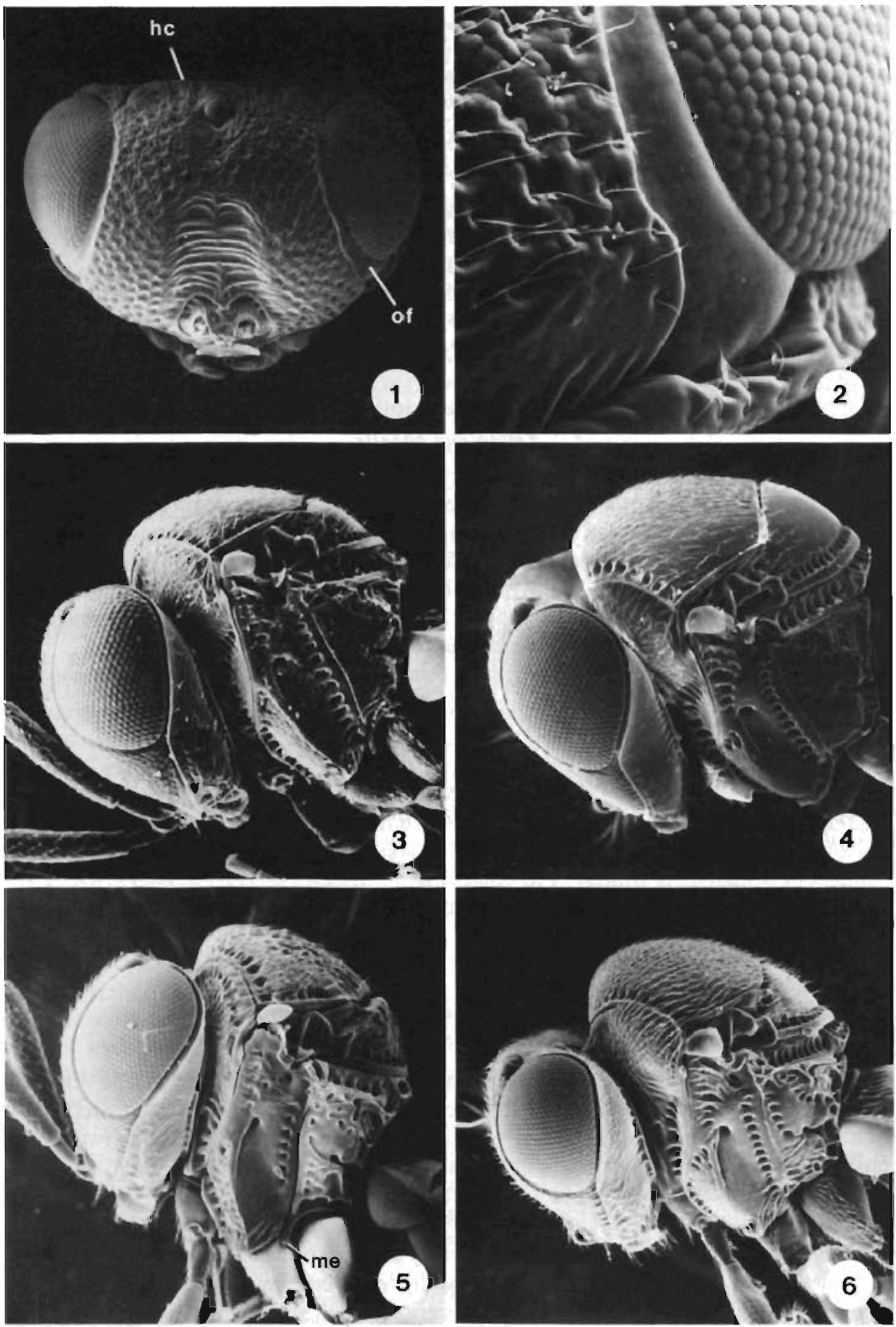

Figs. 1-6. New World Trissolcus spp. 1, $T$. paraguayensis (flavipes species group), head, frontal view; hc: hyperoccipital carena; of: orbital furrow; $68 \times .2$, Trissolcus $\mathrm{sp}$., fiavipes group, detail of orbital furrow; $142 \times$. $3, T$. cosmopeplae, head and mesosoma, lateral view; $94 \times .4, T$. erugatus, head and mesosoma, lateral view; $93 \times .5, T$. solocis, head and mesosoma, lateral view; me: anterior extension of metapleuron; $69 \times .6$, T. utahensis, head and mesosoma, lateral view; $69 \times$ 
7. Seutellum coarsely areolate-rugose; vertex sharply angled onto occiput (Mexico, southeastern

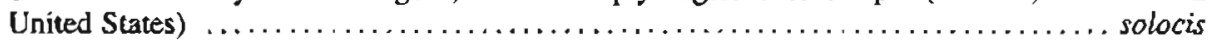

- Scutellum either smooth or with shallowly incised coriaceous microsculpture, median longitudinal carina sometimes present (Fig. 13); vertex rounded onto occiput $\ldots \ldots \ldots \ldots \ldots \ldots$. 8

8. Merapostootum invaginated anterior to mesal expansion of dorsellum, lateral portions of metanorum therefore adjacent to propodeum (Fig. 13); anterior extension of metapleuron toward mid coxa long, acute (Pig. 15); scutellar sculpture variable, usually with coriaceous microsculpture. median longitudinal carina sometimes developed, sometimes scutellum entirely smooth (Canada, United States, Mexico, Dominica, Venezuela) ...........................hullensis

- Metapostsotum invaginated at edges of dorsellum (as in Figs. 14, 16), lateral portions of metanotum therefore separated from propodeum by this sclerite; anterior extension of metapleuron toward mid coxa short (Fig. 4); scutellum usually smooth, sometimes with coriaceous microsculpture (westem United Staces and Canada) ........................... erugarus

\section{Species Descriptions \\ Trissolcus basalis}

Figs. 10, 14

Telenomus basalis Wollaston, 1858: 25, ferale. Type-locality: Madeira Archipelago. Host: unknown. Holotype in BMNH (examined).

Telenomus Maderensis Wollaston, 1858: 25, male, female. Type-locality: Santa Anna, Madeira. Host: unknown. Holotype in BMNH (examined).

Telenomus megacephalus Ashmead, 1894: 212, female. Type-locality: St. Vincent. Host: unknown. Holotype in BMNH (examined).

Telenomus piceipes Dodd, 1920: 354, male, female. Type-locality: Songhor, British East Africa. Holotype in BMNH (examined).

Telenomus basalis: Kieffer, 1926: 39.

Telenomus maderensis: Kieffer, 1926: 39.

Liophanurus megacephalus: Kieffer, 1926: 76.

Microphanurus basalis: Nixon, 1935: 100, fig. 14b.

Microphanurus basalis: Nixon, 1943: 143.

Asolcus basalis: Delucchi, 1961: 57.

Trissolcus basalis: Masner, 1965: 125.

Trissolcus maderensis: Masner, 1965: 126.

Trissolcus piceipes: Masner, 1965: 127.

Asolcus basalis: Safavi, 1968: 415.

Trissolcus basalis: Kozlov and Lê, 1977; 516, figs. 29, 33, 46, 63.

Trissolcus basalis: Kozlov and Kononova, 1983: 121, figs. 218-220.

Length: $1.00-1.3 \mathrm{~mm}(N=20)$. Radicle dark brown to black; claval formula A11-A7/ 1-2-2-2-2; hyperoccipital carina absent, vertex broadly rounded onto occiput; orbital furrow narrow near midpoint of height of eye, constricted and absent dorsally and ventrally; frons outside of antennal scrobes with coriaceous microseulpture throughout (Fig. 10); scrobal depression shallow; central keel poorly defined, not reaching level of midpoint of height of eye, with transverse rugulae arising from keel extending variable distance beyond scrobes; mandibles broad, tridentate, teeth deeply incised, posterior tooth broad, truncate, others acute; head, viewed laferally, with gena distinctly bulging posteriorly; mesoscutum anteriorly with fine raised reticulations, posteriorly with distinct longitudinal rugulae; notauli absent; scutellum with shallowly incised coriaceous microsculpture, setal bases distinctly pustulate (Fig. 14); dorsellum as long laterally as medially, dorsally with single row of deep pits along scutellar margin, below this with single transverse row of areolae, this dorsal area separated from ventral region and laceral portions of metanotum by fine 
raised lip; dorsellum excavate ventrally, striate; lateral portion of metanotum separated from propodeum by metapostnotum; epomial carina well developed; netrion well developed; episternal foveae reduced to pair of rounded pits dorsad of apex of acetabular carina, distinctly separated from crenulae flanking acetabular carina; mesopleural carina absent, anterior margin of depression broadly rounded; anteroventral portion of mesepisternum finely reticulate; anterior extension of metapleuron toward mid coxa long, acute; course of metapleural carina indicated by distinct line of pits; $\mathrm{T} 1$ with 1 pair of sublateral setae; T2 with extensive longitudinal rugulae beyond basal costae, apex smooth, with single subapical transverse line of setae, line broadly interrupted medially; T3 and beyond punctulate basally, with distinct smooth band apically, with single transverse subapical line of setae.

Recorded hosts. Alcaeorrhynchus grandis, Murgantia histrionica, Nezara viridula, Piezodorus guildinii, Podisus maculiventris (Heteroptera: Pentatomidae).

Material examined. $69 \delta \delta, 180 q q$ from the following locations: USA: Florida (Alachua Co., Dade Co., Hillsborough Co.), Louisiana (Baton Rouge Parish), Mississippi (Hancock Co., Jefferson Davis Co., Marion Co.), South Carolina (Barnwell Co., Oconee Co.). West Indies: Bermuda, Cuba, Jamaica, Dominican Republic, Montserrat, Dominica, St. Vincent, Trinidad. South America: Venezuela (Cagua), Brazil (Minas Gerais, Paraná). Australia: Canberra. Africa: Ivory Coast (Bouaké), Republic of South Africa (Pretoria), Zimbabwe (Harare).

Remarks. Within the New World species of Trissolcus, the broadly rounded vertex, wide genae, and rugulose $\mathrm{T} 2$ are found only in $T$. basalis and $T$. utahensis. Trissolcus basalis may be distinguished by its yellow scape (sharply contrasting in color with the dark radicle), abruptly bicolored antennae, and coriaceous scutellum.

Trissolcus basalis is a well-known egg parasitoid of the green vegetable bug, Nezara viridula. Details of the biology and rearing of $T$. basalis have been published a number of times (see especially Cumber 1951, 1964; Kamal 1937; Powell and Shepard 1982; Wilson 1961). Buschman and Whitcomb (1980) reported that the wasp attacks the eggs of several different species of pentatomids in Florida, but that $N$. viridula was its principal host. Sales (1979) has recently reported that females of $T$. basalis are attracted to volatiles from the egg mass of $N$. viridula. This suggests a mechanism for the host specificity of the parasitoid.

Trissolcus basalis has been introduced widely in attempts to suppress $N$. viridula, and has been credited by Caltagirone (1981) with some measure of success in Australia, New Zealand, and Hawaii. As a result of these numerous intentional releases, however, it is now impossible to be certain of the origin of field-collected strains. The native range of the parasitoid is itself uncertain. This species was described from Madeira in 1858 and the West Indies in 1894. In North America the range of the parasitoid roughly mirrors that of its principal host: it is found in the southeastern United States and throughout the West Indies. I have seen no specimens from Mexico or Central America. The range of $T$. basalis in South America is less well known, but it appears to be widespread through the eastern portion of the continent. Powell and Shepard (1982) reported that in spite of some biological differentiation among three stocks from Australia and one from Florida, they all remain interfertile.

The variation within this wasp in the New World seems to be much more limited than that found in other widespread species, e.g. T. brochymenae or T. hullensis. Much more intraspecific variability is found in the African populations of $T$. basalis. In addition, several closely related species occur in Africa, whereas in the New World $T$. utahensis is its only counterpart. The most important host, $N$. viridula is not a native American species; it has been introduced here from the Old World tropics, although its specific place of origin 
is also unclear. All of these factors strongly suggest the $T$. basalis itself was introduced, probably accidentally, into the New World.

\section{Trissolcus cosmopeplae}

Fig. 3

Telenomus cosmopeplae Gahan, 1926: 67, male, female. Type-locality: Urbana, Illinois. Host: Cosmopepla bimaculata (Heteroptera: Pentatomidae). Holotype female in USNM (examined).

Length: $0.8-1.2 \mathrm{~mm}(N=20)$. Radicle dark brown to black, concolorous with scape; claval formula A11-A7/1-2-2-2-2; hyperoccipital carina absent, vertex broadly rounded onto occiput; frons outside of antennal scrobes with coriaceous microsculpture throughout; central keel poorly defined; transverse rugulae variably developed, radiating from central keel, extending outside of scrobes, transverse sculpture lacking entirely in some smaller specimens; orbital furrow narrow near midpoint of height of eye, constricted dorsally and ventrally; mandibles tridentate, teeth shallowly incised, acute; head, viewed laterally, with gena strongly narrowed, not at all bulging; mesoscutum anteriorly with fine raised reticulations, posteriorly with short, weak longitudinal rugulae, longitudinal mesoscutal elements sometimes absent entirely; notauli absent or very short, only 2-3 times as long as wide, much shorter than distance separating them; scutellum smooth; dorsellum as long laterally as medially, excavate ventrally, dorsally with line of deep pits along scutellar margin, ventrally finely striate; lateral portion of metanotum separated from propodeum by metapostnotum; netrion well developed; episternal foveae reduced to single large pit near dorsal apex of acetabular carina; mesopleural carina present; anteroventral portion of mesepisternum coriaceous; anterior extension of metapleuron toward mid coxa long, acute (Fig. 3); course of metapleural carina indicated by distinct line of pits; $\mathrm{T} 1$ with 1 or rarely 2 pairs of sublateral setae; T2 with rugulae extending beyond basal costae, apex smooth; $\mathrm{T} 2$ and following tergites with single subapical transverse line of setae, line on T2 broadly interrupted medially; $\mathrm{T} 3$ and following tergites punctulate.

Recorded host. Cosmopepla bimaculata.

Material examined. $12 \delta^{\star}, 36 \% \%$ from the following localities: Canada: Alberta (Aden, Elkwater L., Lethbridge, Scandia, Waterton), New Brunswick (Kouchibouguac N.P.), Ontario (Carleton Place). USA: Arizona (Coconino Co.), Colorado (Teller Co.), Idaho (Gooding Co.), Mlinois (Champaign Co.), Kansas (Sumner Co.), New Mexico (Dona Ana Co.), South Dakota (Pennington Co.).

Remarks. Trissolcus cosmopeplae may be distinguished from other species with both sublateral setae on $\mathrm{T} 1$ and narrow genae (erugatus, hullensis, radix, and solocis) by the presence of extensive rugulae on T2 and the smooth scutellum. This is also the only New World species outside the thyantae and flavipes groups in which notauli may be visible. All other species usually have the posterior region of the mesoscutum longitudinally striate and the notauli, if present, are thus obscured.

Balduf (1926) has described the biology and immature stages of Trissolcus cosmopeplae. The information provided is essentially the same as that reported for most other telenomine species (see summary of biology in Johnson 1984a). One difference, however, is that this species of wasp is capable of developing in eggs in which the host embryo is already well developed (described as the "pink-eye stage" by Balduf). Most telenomines can successfully parasitize only very young eggs (e.g. Fedde 1977).

\section{Trissolcus erugatus new species}

Fig. 4

Length: $0.8-1.1 \mathrm{~mm}(N=20)$. Radicle brown; hyperoccipital carina absent, boundary between vertex and occiput angulate; female antennal flagellum usually abruptly bicolored, 
Al-A6 yellow, A7-A11 dark brown, sometimes infuscate throughout; claval formula A11-A7/1-2-2-2-2; frontal sculpture somewhat variable, usually with shallowly incised coriaceous microsculpture throughout, some with microsculpture laterally, smooth below median ocellus, scrobal sculpture very weak, with fine transverse rugulae radiating from central keel; orbital furrow narrow near mid point of height of eye, constricted dorsally and ventrally, sometimes obsolete below; mandibles tridentate, teeth acute, shallowly incised; gena, viewed laterally, short, not bulging posteriorly; mesoscutum with fine raised reticulations, with weakly developed longitudinal striae posteriorly; notauli absent; scutellum smooth or with shallowly incised coriaceous microsculpture; dorsellum excavate ventrally, as long laterally as medially, with dorsal line of deep pits flanking scutellar margin, ventral portion longitudinally striate; dorsal portion of dorsellum separated from rest of metanotum by sharp ridge; lateral portion of metanotum separated from propodeum by metapostnotum; epomial carina present; netrion well developed; episternal foveae reduced to 1-3 large, shallow pits near dorsal apex of acetabular carina; mesopleural carina absent ventrally; anteroventral portion of mesepisternum with usually small, finely coriaceous field below episternal pit, otherwise smooth; anterior extension of metapleuron toward mid coxa short, acute (Fig. 4); T1 with 1 pair of sublateral setae; T2 usually smooth beyond basal costae, sometimes with short longitudinal wrinkles; $\mathrm{T} 2$ with single transverse subapical line of setae, line broadly interrupted medially, few setae along T2-laterotergite line of flexion; apex of T2 smooth; T3 and following tergites punctulate, with single irregular transverse subapical line of setae on each.

Recorded host. Thyanta custator (Heteroptera: Pentatomidae).

Material examined. Holotype female: Arizona, Portal, Flyes Park, 6.viii.1977, L. Masner (CNC). Paratypes. Canada. Alberta: Elkwater L., 19-21.vii.1956, O. Peck, swept from grass range, $4 \bigcirc \%$ (CNC). Scandia, 2.vii. 1956, O. Peck, swept from alfalfa (Medicago sativa, Leguminosae), 1 (CNC). USA. Arizona: Cochise Co., Chiricahua Mts., SW Research Station, 5400' el. [1646 m], 11.vi. 1980, V. Roth, $3 \%$ (CNC). California: Kern Co., Shafter, 30.vii.1936, G.L. Smith, ex Thyanta custator, 10 (USNM); Placer Co., $4 \mathrm{mi}[6.4 \mathrm{~km}$ ] S Rocklin, 2.v.1979, Malaise trap 8AM-5PM, Wasbauer, Adams, 29 (CDFA); San Bernardino Co., 6 mi [9.6 km] N 29 Palms, 14.v.1981, J. LaSalle, 19 (NFJ); Baldy Mesa, 6 mi E Phelan, 6-12.vi.1981, J.T. Huber, 19 (NFJ); same data as preceding specimen, collected 26.vi-3.vii, 29 (NFJ); $2 \mathrm{mi}[3.2 \mathrm{~km}] \mathrm{N}$ Wrightwood, 9. viii. 1978, G. Gordh, 1 ㅇ (UCR); San Diego Co., Anza-Borrego St. Pk., 15.iv.1981, J. Huber, swept, $4 \delta^{*} \delta$ (NFJ); Shasta Co., Redding, 28.vi. 1935, R.H. Beamer, 19 (Snow); Siskiyou Co., Etna, 1-5.x.1978, F.D. Horn, $1 \delta^{\dagger}$ (CDFA); Helendale, 21.v.1955, W.R.M. Mason, 1 ㅇ (CNC).

Remarks. Trissolcus erugatus may be distinguished from the most common southwestern species of Trissolcus discussed here, $T$. utahensis, by its strongly narrowed genae, angulate vertex, and the lack of rugulae on T2 (occasionally rugulae are present, but these are very short in comparison with utahensis). It may be distinguished from $T$. hullensis by the following characters: metapostnotum not invaginated anterior of mesal expansion of dorsellum; anterior extension of metapleuron toward mid coxa short; mandibular teeth shallowly incised; mesopleural carina absent; legs and A1-A6 usually yellow. Trissolcus cosmopeplae may usually be separated from erugatus by the strong development of rugulae on $\mathrm{T} 2$ and the long extension of the metapleuron toward the mid coxa in the former species. of $\mathrm{T} 2$.

The name erugatus from the Latin for clear of wrinkles, refers to the sculpture

Trissolcus erugatus seems to be a rather isolated species within the New World fauna of the genus. The narrowed genae ally it with hullensis, solocis, radix, and cosmopeplae, but the condition of the metapostnotum, mandibular teeth, and metapleural extension usually distinguish it quite clearly. Specimens from the southwest are easily identifiable, but 
variation in color and sculpture in the northern part of its range may result in confusion between this species and cosmopeplae.

\section{Trissolcus hullensis}

Figs. 7, 8, 13, 15, 17

Telenomus hullensis Harrington, 1899: 182, female. Type-locality: Hull, Quebec. Host: unknown. Holotype in CNC (examined).

Telenomus hullensis: Kieffer, 1926: 40.

Trissolcus hullensis: Johnson, 1984a.

Length: 0.8-1.4 mm $(N=20)$. Radicle black; claval formula A11-A7/1-2-2-2-2; hyperoccipital carina absent, vertex abruptly rounded onto occiput; frons with coriaceous microsculpture throughout, setae inserted into small punctures; antennal scrobes with rugulae radiating from central keel, rugulae extending variable distance onto frons, sometimes very strongly developed, sometimes absent altogether (see Figs. 7, 8); orbital furrow present near midpoint of height of eye, narrow, constricted dorsally and ventrally; mandibles tridentate, teeth deeply incised, acute; head, viewed laterally, with gena narrow, not bulging posteriorly; mesoscutum with coriaceous microsculpture throughout, anteriorly with raised reticulations, posteriorly with distinct longitudinal rugae; notauli absent; scutellar sculpture variable: usually with coriaceous microsculpture throughout and more or less well-developed median longitudinal carina (as in Fig. 13), sometimes carina absent altogether, some specimens from southwestern USA with scutellum entirely smooth; dorsellum as long medially as laterally, excavate ventrally, with dorsal row of deep pits along scutellar margin, this continuous with pits on lateral portions of metanotum, ventrally dorsellum striate; metapostnotum invaginated distinctly anterior to mesal expansion of dorsellum, dorsal margin of propodeum therefore contiguous with lateral portions of metanotum near dorsellum (Fig. 13); epomial carina present, short; netrion well developed; episternal foveae present, 2-3 shallow, poorly delimited impressions; mesopleural carina present; anteroventral portion of mesepisternum coriaceous; anterior extension of metapleuron toward mid coxa long, acute (Fig. 15); course of metapleural carina indicated by distinct line of pits; T1 with 1 pair of sublateral setae; T2 sculpture variable, usually smooth beyond basal costae (Fig. 17), sometimes with weak longitudinal wrinkles, apex always smooth; T2 and following tergites with single subapical transverse line of setae, this line on T2 broadly interrupted medially; T3 and following tergites punctulate.

Recorded hosts. Apateticus bracteatus, Nezara viridula, Podisus maculiventris, Thyanta sp. (Heteroptera: Pentatomidae).

Material examined. $23 \delta^{\circ} \delta, 171 \% q$ from the following localities: Canada: Alberta (Aden, Aspen Beach, Edmonton, Elkwater, Lethbridge, Onefour, Scandia, Slave L.), Manitoba (Riding Mtn. N.P.), New Brunswick (Kouchibouguac N.P.), Nova Scotia (Canard), Ontario (Carleton Place, Spencerville), Quebec (Hull, Cap Rouge), Saskatchewan (White Fox, Snowden, Saskatoon Ldg.). USA: Arizona (Cochise Co., Graham Co., Pima Co.), Arkansas (Mississippi Co.), California (Imperial Co., Inyo Co., Los Angeles Co., Riverside Co., San Bernardino Co., San Diego Co.), Colorado (Boulder Co., Jefferson Co.), Florida (Alachua Co., Dade Co., Monroe Co., Pinellas Co.), Idaho (Fremont Co., Gooding Co.), Maine (Kennebec Co.), Maryland (Anne Arundel Co.), Massachusetts (Middlesex Co.), Montana (Ravalli Co.), New Hampshire (Strafford Co.), New Mexico (Hidalgo Co., Lincoln Co., Valencia Co.), North Carolina (Watauga Co.), Ohio (Franklin Co.), Oregon (Benton Co., Washington Co.), South Dakota (Pennington Co.), Texas (Blanco Co., Brazos Co., Brewster Co., Calhoun Co.). Mexico: Baja California Sur, Districto Federal, Puebla, Sonora. Dominica. Venezuela (Cagua).

Remarks. Trissolcus hullensis is most closely related to two southern species, $T$. solocis and $T$. radix. All three of these species have the metapostnotum invaginated into the 

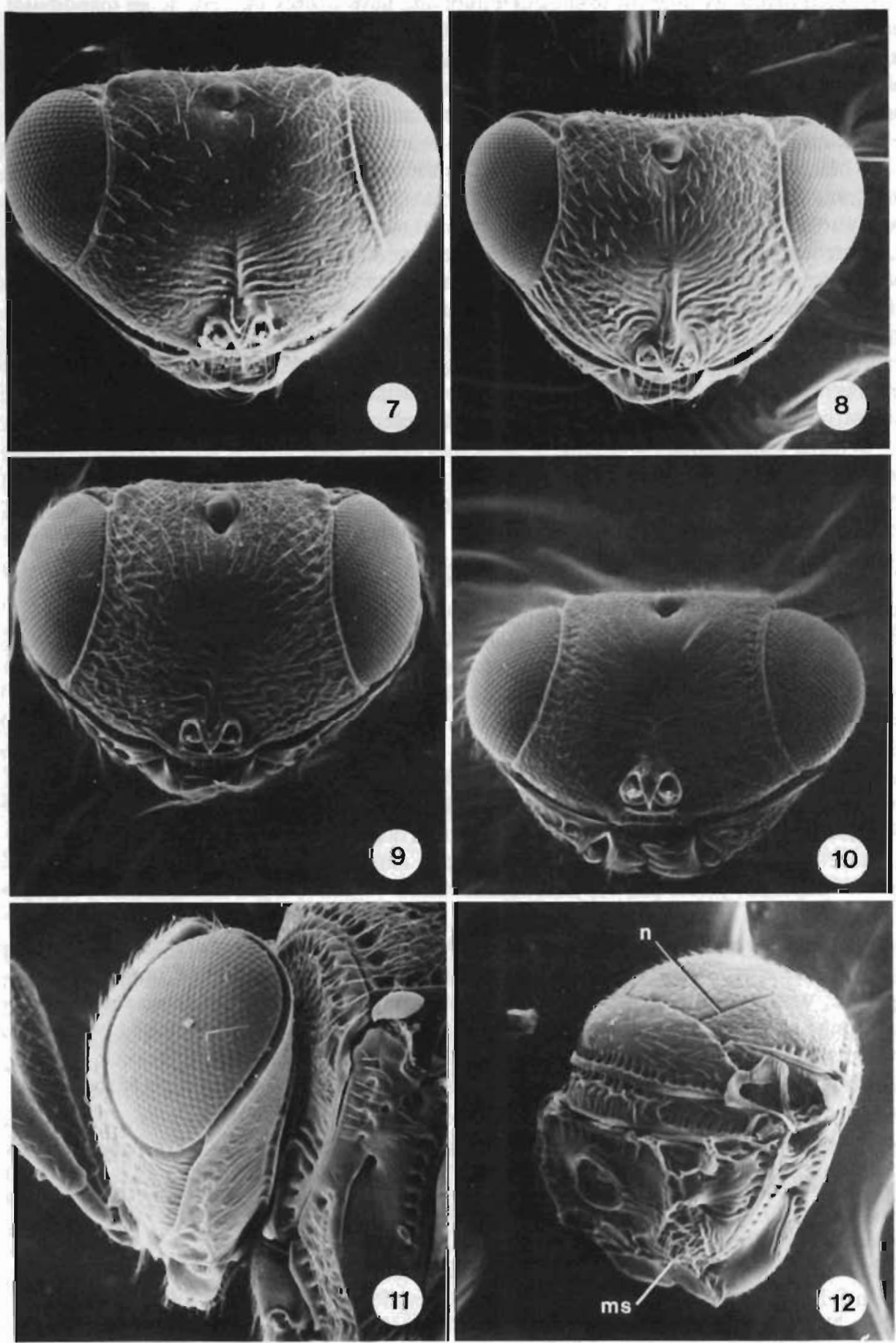

FIGS. 7-12. New World Trissolcus spp., head, frontal view, 7, T. hullensis, Ontario specimen; $117 \times, 8, T$. hullensis, Montana specimen: $77 \times .9 . T$. solocis: $81 \times .10 . T$. hasalis; $97 \times .11, T$. solocis, head, lateral view; $99 \times$. 12, T. thyantae, mesosoma, posterolateral view; $n$ : notaulus; $m s$ : metapleural setae; $79 \times$. 
mesosoma distinctly anterior to the dorsellum and have deeply incised, acute mandibular teeth. Trissolcus hullensis may be distinguished from the other two by the scutellar sculpture, coriaceous or smooth in southem specimens of hullensis, coarsely areolate in the other two species; the color of the radicle, black in hullensis and solocis, yellow in radix; and the rounded vertex, sharply angled in radix and solocis.

Trissolcus hullensis, as interpreted here, is a species of great variability. Characters that I believe to be especially variable include the development of rugae on the frons, the background sculpture of the scutellum, the degree of development of a median longitudinal crest on the scutellum, the extent of longitudinal rugulae on T2, and the color of the legs and antennae. If taken individually, the extreme states found in these characters would lead to the recognition of at least $2-3$ species. I have, however, found many specimens with intermediate conditions as well as different combinations of extreme characters. I have therefore decided to treat all these forms as a single species. Generally, specimens from Florida seem to have lighter-colored appendages, specimens from Mexico and the southwestern USA have very weakly developed scutellar sculpture, and specimens from the northern Nearctic have the most strongly developed sculpture.

This is a widespread and fairly common species, found almost throughout the entire Nearctic. I find it unusual, therefore, that $T$. hullensis has not been recorded since its original description in 1899 ! Data on hosts are sparse; this wasp must attack the eggs of pentatomid species that are not economically important.

\section{Trissolcus radix new species}

Length: 1.2-1.4 mm $(N=8)$. Radicle yellow; claval formula A11-A7/1-2-2-2-2; hyperoccipital carina absent, vertex abruptly angled onto occiput; frontal sculpture dominated by rugulae radiating from central keel, these superimposed on granulose microsculpture; central keel weak, extending from interantennal prominence to preocellar pit; orbital furrow very narrow, raised mesal margin indistinct ventrally; mandibles tridentate, teeth deeply incised, acute; head, viewed laterally, with gena very narrow, not at all bulging; mesoscutum with granulose microsculpture throughout, in anterior two-thirds with superimposed irregular rugae, posteriorly longitudinally rugose; notauli absent; scutellum with same sculpture as anterior portion of mesoscutum; dorsellum as long laterally as medially, excavate ventrally, with dorsal row of deep pits along scutellar margin, ventral portion narrow, punctate, dorsal pits separated from ventral region and pits along lateral portions of metanotum by raised ridge; metapostnotum invaginated distinctly laterad of dorsellum; epomial carina present; netrion well developed; episternal foveae reduced to 2-3 poorly defined punctures; mesopleural carina present; anteroventral portion of mesepisternum rugulose, with granulose microsculpture; anterior extension of metapleuron toward mid coxa long, acute; course of metapleural carina indicated by pits, but obscured by coarse surface sculpture of sclerite; T1 with 1 pair of sublateral setae; T2 with weak rugulae extending beyond basal costae; T2 and following tergites with single subapical transverse line of setae; T3 and following tergites punctulate.

Kecorded host. Euthyrhynchus floridanus (Pentatomidae).

Material examined. Holotype female: Florida: Alachua Co., S9-T1ES-R18E, Pierce's Homestead, 29.xii. 1973, Malaise trap, WH Pierce (FSCA). Paratypes. South Carolina: Barnwell Co., Blackville; 9.xii.1975; W.A. Jones; ex Euthyrhynchus floridanus, 39 ㅇ (NFJ). Guatemala: from coffee, 5.v.1964, 19 (USNM). Costa Rica: Prov. Puntarenas, $10 \mathrm{~km}$ S Monteverde, approx. 3000' [914 m], 9.xi.1980, J.B. Woolley, 19 (NFJ). Colombia: Norte de Santander, $20 \mathrm{mi}$ [32.2 km] S Cucuta, 2500' [762 m], 8.v.1974, J. Peck, 19 (CNC). Venezuela: Mérida, $1800 \mathrm{~m}$ el., 6.v.1981, L. Masner, 1 q (CNC).

Remarks. Trissolcus radix is most closely related to $T$. hullensis and $T$. solicis, from which it may be distinguished by the bright yellow radicle.

The name radix, from the Latin for root, refers to the distinctive yellow radicle. 


\section{Trissolcus solocis new species}

Figs. 5, 9, 11

Length: $0.9-1.3 \mathrm{~mm}(N=20)$. Radicle black; claval formula A11-A7/1-2-2-2-2; vertex sharply angled onto occiput, similar to hyperoccipital carina but without differentiated ridge; frons with granulose microsculpture throughout, laterad of scrobes with superimposed irregular rugae (Fig. 9); scrobes with well-developed transverse rugae radiating from central keel; orbital furrow narrow, poorly defined ventrally; mandibles tridentate, teeth acute, deeply incised; gena, viewed laterally; short, not bulging; mesoscutum with coriaceous microsculpture, anteriorly with superimposed raised reticulations, posteriorly longitudinally strigose; notauli absent or obscured by coarse sculpture; scutellum with same sculpture as anterior part of mesoscutum; dorsellum excavate ventrally, as long laterally as medially, with dorsal row of deep pits flanking scutellar margin; ventral portion short, punctate, dorsal pits separated by raised ridge from ventral lip and pits along lateral portions of metanotum; epomial carina present; netrion well developed; episternal foveae reduced to 2 shallow pits near dorsal apex of acetabular carina; mesopleural carina present; anteroventral portion of mesepisternum rugulose; anterior extension of metapleuron toward mid coxa long, acute (Fig. 5); dorsal portion of metapleuron + propodeum with longitudinal row of pits below spiracle obscured by irregular carinae; $\mathrm{T} 1$ with 1 pair of sublateral setae; T2 smooth beyond basal costae; $\mathrm{T} 3$ and following tergites punctulate; setae on $\mathrm{T} 2$ and following tergites as in $T$. hullensis.

Hosts. Acrosternum marginatum, Nezara viridula, Podisus maculiventris, Alcaeorrhynchus grandis (Heteroptera: Pentatomidae).

Material examined. Holotype female: Florida: Alachua Co., Gainesville, 15.xi.1974, L. Buschman; Host: on eggs of Acrosternum marginatum; Trissolcus n. sp. = T. "B" (FSCA). Paratypes. Mexico: Cuernavaca, 1953, J. Mann, ex eggs Hemiptera, 10 females (USNM). USA. Florida: with same locality data as holotype, collected from or on eggs of Nezara viridula on the following dates: 7, 28.x.1974; 4, 11, 15, 22.xi.1974; 18.x.1975; 13ㅇ; reared from eggs of Alcaeorrhynchus grandis on 1.x.1975; 11.xi.1975; $3 \hat{\sigma}^{\hat{\alpha}} \hat{\sigma}^{*}$, $49 \%$; reared from eggs of Podisus maculiventris on 22.x.1975, $1 \%$; reared from eggs of Acrosternum marginatum on 15.xi.1974; 22.x.1975; 6 $\delta^{\circ}, 7 \% q$ (FSCA, CNC, USNM, NFJ). Other material: Mexico: Morelos, Koebele, 1229, $3 \delta^{\star} \delta, 2 \% q$ (CAS, USNM). In addition many specimens were seen that were collected in Gainesville in November and December, 1974 and December, 1975.

Remarks. Trissolcus solocis may be distinguished from the closely related $T$. hullensis by the coarse sculpture of the scutellum. From $T$. radix it may be most easily separated by its black radicle.

The name solocis, from the Latin for coarse or rough, refers to the sculpture of the scutellum.

Trissolcus solocis was collected and reared in large numbers by Buschman and Whitcomb (1980, discussed as Trissolcus sp. B). They reported that it was a common species and an important parasitoid of the eggs of Acrosternum, Alcaeorrhynchus, and Murgantia. Little else is known of the wasp; from the few collection records available it appears to be a subtropical - northern Neotropical species.

\section{Trissolcus utahensis}

Figs. 6, 16, 18

Telenomus utahensis Ashmead, 1893: 148, male, female. Type-locality: Wasatch, Utah. Host: unknown. Lectotype (examined) in USNM.

Hadronotus mesillae Cockerell, 1897: 25, male. Type-locality: Las Cruces, New Mexico. Host: Pentatomidae. Holotype (examined) in USNM. 

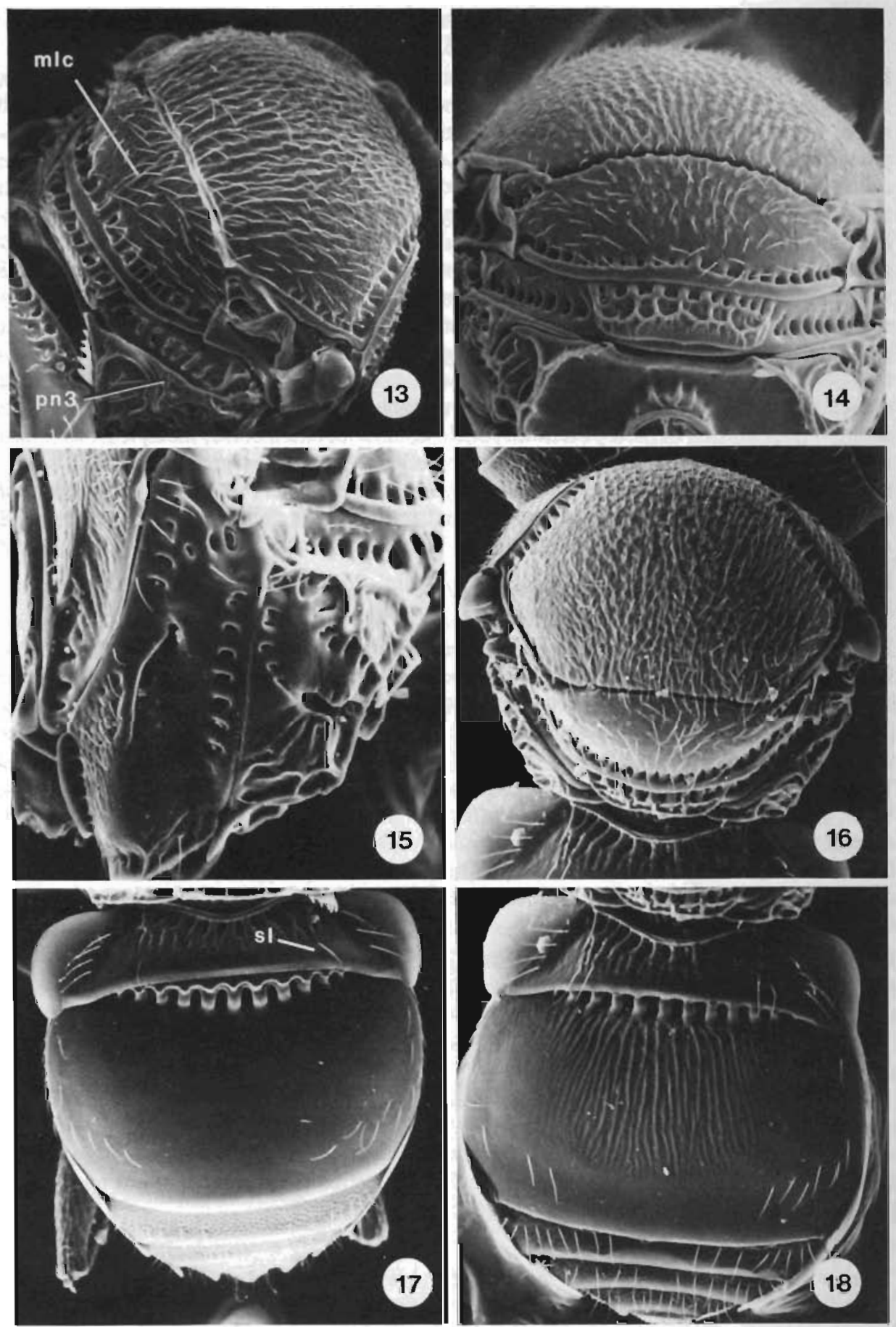

Fics. 13-18. New World Trissolcus spp. 13, T. hullensis, mesosoma, posterodorsal view; mlc median longitudinal carina; pn3: metapostnotum; $107 \times .14, T$. basalis, mesosoma, posterior view; 131 $\times .15,7$. hullensis, mesosoma, lateral view; $165 \times .16, T$. urahensis, mesosoma, dorsal view: $103 \times .17 . T$. hullensis, metasoma, dorsal view; sl: sublateral seta; $84 \times .18, T$. utahensis, metasoma, dorsal view; $95 \times$. 
Telenomus ashmeadi Morrill, 1907: 419, figs. 1b, 2, male, female. Type-locality: Barstow, Texas. Host: Chlorochroa ligata (Heteroptera: Pentatomidae). Lectotype (examined) in USNM.

Telenomus ashmeadi: Kieffer, 1926: 48.

Liophanurus utahensis: Kieffer, 1926: 73.

Hadronotus mesillae: Kieffer, 1926: 464.

Telenomus mesillae: Gahan, 1932: 757.

Trissolcus ashmeadi: Masner and Muesebeck, 1968: 71 (lectotype designation).

Trissolcus utahensis: Masner and Muesebeck, 1968: 74 (lectotype designation).

Length: 0.9-1.7 mm $(N=20)$. Radicle dark brown to black; claval formula A11-A7/12-2-2-2; hyperoccipital carina absent, vertex broadly rounded onto occiput; frons outside of antennal scrobes with coriaceous microsculpture throughout; antennal scrobes with weakly developed central keel, keel not reaching anterior ocellus; scrobes with transverse rugulae radiating from central keel, rugulae extending variable distance beyond scrobes; preocellar pit present, circular; orbital furrow narrow near midpoint of height of eye, constricted dorsally and ventrally; mandibles broad, tridentate, teeth shallowly incised, broad; head, viewed laterally, with gena distinctly bulging posteriorly; mesoscutum anteriorly with fine raised reticulations, longitudinally rugulose posteriorly; notauli absent; scutellum smooth (Fig. 16); dorsellum as long laterally as medially, dorsally with line of deep pits adjacent to scutellum, below this with line of areolae, these areas separated from ventral part of dorsellum and lateral portions of metanotum by fine raised lip; dorsellum excavate ventrally, punctulate; metapostnotum not invaginated laterad of dorsellum; epomial carina well developed; netrion well developed; episternal foveae represented by chain of 3-4 elongate pits extending from dorsal apex of acetabular carina toward mesopleural pit; mesopleural carina absent; anteroventral portion of mesepisternum largely smooth, with field of fine coriaceous microsculpture beneath episternal foveae; anterior extension of metapleuron toward mid coxa short, acute (Fig. 6); course of metapleural carina indicated by distinct line of pits; T1 with 1-2 pairs of sublateral setae; T2 with extensive longitudinal rugulae beyond basal costae (Fig. 18), apex smooth; T2 and following tergites with single subapical transverse line of setae; T3 and following tergites punctulate.

Recorded hosts. Chlorochroa sayi, C. ligata, Euschistus impictiventris, Thyanta custator (Heteroptera: Pentatomidae).

Material examined. $127 \delta \delta, 384 q q$ from the following locations: Canada: Alberta (Aden, Edmonton, Lethbridge, Medicine Hat, Onefour, Waterton), British Columbia (Victoria), Saskatchewan (Moose Jaw). USA: Arizona (Cochise Co., Maricopa Co., Yuma Co., Sitgreaves National Forest), California (Alameda Co., Fresno Co., Imperial Co., Inyo Co., Kern Co., Kings Co., Los Angeles Co., Mono Co., Monterey Co., Placer Co., Riverside Co., San Bernardino Co., Shasta Co., Siskiyou Co., Ventura Co., Santa Cruz Mtns.), Colorado (Boulder Co., Mesa Co., Teller Co.), Idaho (Ada Co., Cassia Co., Fremont Co., Gooding Co., Owyhee Co., Power Co., Twin Falls Co.), Kansas (Sumner Co.), Nevada (Lyon Co.), New Mexico (Colfax Co., Dona Ana Co., Lincoln Co., Santa Fe Co.), South Dakota (Pennington Co.), Texas (Brazos Co., Culberson Co., Presidio Co., Ward Co.), Utah (Cache Co., Millard Co., Salt Lake Co., Summit Co., Wasatch Co., Washington Co., Utah Co.), Washington (Pierce Co.), Wyoming (Park Co.).

Remarks. Trissolcus utahensis is a relatively dark-colored species, usually rather large. Some specimens from the southern part of its range have lighter-colored appendages. In the Nearctic region it is most similar to $T$. basalis. The two may be distinguished by the color of $\mathrm{A} 1$, usually dark, concolorous with the radicle in utahensis, yellow, sharply contrasting with the dark radicle in basalis; and the scutellar sculpture, smooth in utahensis, coriaceous in basalis. 
Trissolcus utahensis is a common species of the western Nearctic region. Its principal hosts appear to be species of the genus Chlorochroa, although other pentatomid genera have been recorded. The wasp occurs in a variety of habitats. It has been collected on several different commercial crops (tomato, wheat, cotton, alfalfa, strawberries) as well as wild carrot (Daucus carota, Umbelliferae), Ponderosa pine (Pinus ponderosa, Pinaceae), Agropyron cristatum (Gramineae), Bromus sp. (Gramineae), Salsola kali and Salsola pestifer (Chenopodiaceae). Some aspects of its biology have been discussed by Morrill (1907, as Telenomus ashmeadi) and Jubb and Watson (1971, as Telenomus utahensis).

\section{ACKNOWLEDGMENTS}

I thank W. F. Barr (Moscow, ID), G. Byers (Lawrence, KS), N. D. M. Fergusson (London), J. Hall (Riverside, CA), W. Jones (Stoneville, MS), P. M. Marsh (Washington, DC), L. Masner (Ottawa, ON), A. Newton (Cambridge, MA), P. Arnaud (San Francisco, CA), R. R. Snelling (Los Angeles, CA). L. Stange (Gainesville, FL), and M. S. Wasbauer (Sacramento, CA) for the kind loans of specimens; and D. C. Darling (Corvallis, OR) for comments on the manuscript. This material is based on work supported by the National Science Foundation under Grant No. DEB-8201082.

\section{References}

Ashmead, W.H. 1893. A monograph of the North American Proctotrypidae. Bull. U.S. natn. Mus. 45.472 pp.

1894. Report on the parasitic Cynipidae, part of the Braconidae, the Ichneumonidae, the Proctotrypidae, and part of the Chalcidinae. Part III. Zool. J. Linn. Soc. Lond. 25: 188-254.

Balduf, W.V. 1926. Telenomus cosmopeplae Gahan, an egg parasite of Cosmopepla bimaculata Thomas. $J$. econ. Ent. 19: 829-841.

Bin, F. 1981. Definition of female antennal clava based on its plate sensilla in Hymenoptera Scelionidae Telenominae. Redia 64: $245-261$.

Buschman, L.L. and W.H. Whitcomb. 1980. Parasites of Nezara viridula (Hemiptera: Pentatomidae) and other Hemiptera in Florida. Fla Ent. 63: 154-162.

Caltagirone, L.E. 1981. Landmark examples in classical biological control. A. Rev. Ent. 26: 213-232.

Cockerell, T.D.A. 1897. A parasite of hemipterous eggs. Can. Ent. 29: 25-26.

Cumber, R.A. 1951. The introduction into New Zealand of Microphanurus basalis Woll. (Scelionidae: Hym.), egg-parasite of the green vegetable bug, Nezara viridula L. (Pentatomidae). N.Z. Jl Sci. Tech. Sec. B. 32(5): $30-37$.

- 1964. The egg-parasite complex (Scelionidae: Hymenoptera) of shield bugs (Pentatomidae, Acanthosomidae: Heteroptera) in New Zealand. N.Z. Jl Sci. 7: 536-554.

Delucchi, V.L. 1961. Le complexe des Asolcus Nakagawa (Microphanurus Kieffer) (Hymenoptera, Proctotrupoidea) parasites oophages des punaises des ceréales au Maroc et au Moyen-Orient. Cah. Rech. Agron. 14: $41-67$.

Dodd, A.P. 1920. VIrI. Notes on the exotic Prnctotrupoidea in the British and Oxford University Museums, with descriptions of new genera and species. Trans. ent. Soc. Lond. 1919: 321-382.

Fedde, G. 1977. A laboratory study of egg parasitization capabilities of Telenomus alsophilae. Environ. Ent. 6: $773-776$.

Gahan, A.B. 1926. A new egg-parasite (Hymenoptera: Serphoidea). Proc. ent. Soc. Wash. 28: 67.

1932. Miscellaneous descriptions and notes on parasitic Hymenoptera. Ann. ent. Soc. Am. 25: 736757.

Harrington, W.H. 1899. Catalogue of Canadian Proctotrypidae. Trans. R. ent. Soc. Can. (2) 5(4): 169-206.

Johnson, N.F. 1984a. Systematics of Nearctic Telenomus: classification and revisions of the podisi and phymatae species groups (Hymenoptera: Scelionidae). Bull. Ohio biol. Surv. (n.s.) 6(3). $113 \mathrm{pp}$.

- 1984b. Revision of the Nearctic species of the Trissolcus flavipes group (Hymenoptera: Scelionidae). Proc. ent. Soc. Wash. 86: 797-807.

1985. Revision of the New World species of the thyantae group of Trissolcus (Hymenoptera: Scelionidae). Can. Ent. 117: 107-112.

Jubb, G.L., Jr. and T.F. Watson. 1971. Parasitization capabilities of the pentatomid egg parasite Telenomus utahensis (Hymenoptera: Scelionidae). Ann. ent. Soc. Am. 64: 452-456.

Kamal, M. 1937. The cotton green bug, Nezara viridula, L. and its important egg-parasite, Microphanurus megacephalus (Ashmead) (Hymenoptera - Proctotrupoidea). Bull. Soc. ent. Egypte 21: 175-207.

Kieffer, J.J. 1926. Scelionidae. Das Tierreich. Vol. 48. Walter de Gruyter, Berlin. 885 pp.

Kozlov, M.A. and S.V. Kononova. 1983. [Telenomines of the fauna of the USSR. Determinations of the Fauna 
of the USSR, published by the Zoological Institute, Academy of Sciences, USSR.] Publishing House "Nauka", Leningrad. 335 pp.

Kozlov, M.A. and Lê Xuân Huê. 1977. [Palearctic species of egg parasites of the genus Trissolcus Ashmead, 1893 (Hymenoptera, Scelionidae, Telenominae).] Insects of Mongolia 5: 500-525.

Masner, L. 1965. The types of Proctotrupoidea (Hymenoptera) in the British Museum (Natural History) and in the Hope Department of Entomology, Oxford. Bull. Brit. Mus. nat. Hist. Ent. Suppl. 1.154 pp. 1979. The variicornis-group of Gryon Haliday (Hymenoptera: Scelionidae). Can. Ent. 111: 79l-805. 1980. Key to genera of Scelionidae of the Holarctic region, with descriptions of new genera and species (Hymenoptera: Proctotrupoidea). Mem. ent. Soc. Can. 113. 54 pp.

Masner, L. and C.F.W. Muesebeck. 1968. The types of Proctotrupoidea (Hymenoptera) in the United States National Museum. Bull. U.S. natn. Mus. 270.143 pp.

Morrill, A.W. 1907. Description of a new species of Telenomus with observations on its habits and life history. Am. Nat. 41: 417-430.

Nixon, G.E.J. 1935. A revision of the African Telenominae (Proctotrupoidea, fam. Scelionidae). Trans. R. ent. Soc. Lond. 83: 73-103.

1938. Five new Asiatic Telenominae (Hym., Proctotrupoidea). Ann. Mag. nat. Hist. (11)1: 584-593. 1943. A synopsis of the Ethiopian and Indo-Malayan species of Microphanurus (Serphoidea, Scelionidae). Bull. ent. Res. 34: 135-144.

Powell, J.E. and M. Shepard. 1982. Biology of Australian and United States strains of Trissolcus basalis, a parasitoid of the green vegetable bug, Nezara viridula. Aust. J. Ecol. 7: 181-186.

Safavi, M. 1968. Étude biologique et ecologique des hyménoptères parasites des oeufs des punaises de cérÉales. Entomophaga 13: $381-495$.

Sales, F.M. 1979. Responsiveness and threshold for host-seeking stimulation of the female Trissolcus basalis (Wollaston) by the eggs of the host, Nezara viridula (L.). Fitossanidade 3(1-2): 36-39.

Wilson, F. 196I. Adult reproductive behavior in Asolcus basalis (Hymenoptera: Scelionidae). Aust. J. Zool. 9: 793-751.

Wollaston, T.V. 1858. Brief diagnostic characters of undescribed Madeiran insects. Ann. Mag. nat. Hist. (3)1: $18-28,113-125$.

(Date received: 198406 20; date accepted: 198409 09) 